\title{
Legal and Institutional Framework: The "Achilles Heel” Of Local Authorities and Raison D'etre of Ministerial Intervention in Zimbabwe
}

\author{
Alois Madhekeni (Corresponding author) \\ Department of Political and Administrative Studies Faculty of Social Studies University of \\ Zimbabwe, P.O.Box MP 167 MT Pleasant Harare Zimbabwe \\ Phone: +263772 754831 e-mail: madhekeni@yahoo.com
}

Gideon Zhou

Department of Political and Administrative Studies Faculty of Social Studies University of Zimbabwe

Received: June 29, 2012 Accepted: July 28, 2012 DOI: 10.5296/jpag.v2i3.2017

\begin{abstract}
Centre-local relations have been an area of controversy in Zimbabwean local governance both as a discipline and as a practice. Local authorities have traded blows with central government particularly accusing the responsible Ministry of reducing them to spectators in their own field through excessive ministerial intervention. Meanwhile the ministry of local government has cracked the whip on local authorities accusing them of mismanagement and compromised service delivery. The independent media has described the scenario as a "Bloodbath" in local authorities. The bone of contention has been largely on the devolution of local authority issues, expanding the autonomy of the periphery from the center and clipping the powers of the responsible Minister. What appears to be misconstrued by many however is the fact that the governing legal and institutional framework of local governance in Zimbabwe provides room for the responsible Minister to legally enable or disable local authority administration. This governing framework has been and is still the "Achilles heel" of local authorities and the raison d'être of ministerial intervention in Zimbabwe.
\end{abstract}

Keywords: Ministerial intervention, Institutions, Central government, Legislation, Local government 


\section{Introduction}

The article examines the legal and institutional framework of local government in Zimbabwe. The endeavour is to establish the nature and scope of the relationship between central government and local authorities as shaped by the governing legislation and enforced through the established institutions. Generally local government refers to the control and organisation of towns and small areas by people who are elected from them. Helmsing (1990) defines local government as a government structure whose legislative and executive powers are exercised by locally elected representatives. It therefore follows that local authorities are a lower tier of government, set up by law and conferred with certain responsibilities and whose leadership is locally elected. It also follows that local governance is a democratic move to provide residents with a platform to govern themselves and champion their own affairs. In reality however it is worth noting that local authorities are not independent from central government as the later not only defines the legal framework within which the former operates but also constantly monitors its performance and conduct. It is the argument of this paper that the legal and institutional framework of local government in Zimbabwe is the most vulnerable part like the mortal heel of the ancient great Greek warrior, Achilles. The Ministry of Local Government can thus intervene in and control councils through this framework and still remain intra wires.

\section{Background in Zimbabwe}

The history of local governance in Zimbabwe dates back to the 1890s with the arrival of the British South African Company (BSAC) and the subsequent establishment of the first formal local authority, the Salisbury Sanitary Board (Jordan, 1984). Subsequent years saw the introduction of Municipal Ordinances, Advisory Boards in African townships and African Councils under the direct rule of the District Commissioner's Office. These structures laid the foundation of a highly centralized local governance system based on white supremacist policies and characterized by the imposition of substandard and centrally defined programmes on African and Native Councils and denial of African self-government.

This manifestation of central government dominance in local authorities through entrenched draconian and racial legal and institutional frameworks was later on met with strong resistance and contradiction by the black populace through the liberation struggle. The deposition of the colonial regime in led to a new twist in the local government arena with the installation of new structures, expanded decentralization of local government structures and ZANU PF's liberation interventions sowing the seeds for political party intervention and control over local authorities.

The dawn of independence in 1980 saw the creation of a single local government Ministry and the amalgamation of African Councils into District Councils and the establishment of new legislation (Rural District Councils Act and the Urban Councils Act). In spite of Zimbabwe's independence from the colonial regime, the new legal and institutional framework of local government did not depose nor loosen the central government's stranglehold on local authorities. The post-independence era has been characterized by what 
Olowu (2001) refers to as expanded "centralization through decentralization" where central government purports to promote the principles of decentralization by transferring tasks and responsibilities to local authorities whilst retaining decision making power and authority.

Government perfected this strategy by fostering central government control through crafting legal and institutional frameworks that gave the responsible Ministry of Local Government unlimited and unchecked powers and discretion whilst the institutional framework provides the necessary levers to execute the powerful legal provisions. Whilst the need for checks and balances on local authorities need not be overemphasized the dynamics of post-independence Zimbabwe are slowly turning into a déjà vu as the machinations of colonial period municipal ordinances, African Councils and the District Commissioner's office appear to start haunting contemporary local government administration.

\section{Legal Framework}

Local authorities in Zimbabwe are creatures of central government established through legislation rather than the constitution. The Urban Councils Act (Chapter 29:15) and the Rural District Councils Act (Chapter 29:13) provides for the establishment of Urban Councils and Rural District Councils respectively. The pieces of legislation determine the powers, functions and locus of local authorities. They shape urban and rural local governance and constitute the tools available to the Ministry of Local Government Urban and Rural Development to supervise, monitor, direct and control local authorities. The balance of power enshrined in the numerous pieces of legislation reflects the "mortal" and ultimate vulnerability or protection which local authorities suffer or enjoy from the center. Zimbabwe has a heavy-handed legal framework which accords unlimited power, authority and discretion to the Ministry and leaves councils at the mercy of the responsible minister who can easily manipulate, whip, politicize and jettison them and still remain intra wires.

\subsection{Local Government legislation in the pre-independence era}

Before independence Zimbabwe was colonized by a British company, the British South African Company (BSAC) which arrived in 1890 and introduced a western model of local governance. In 1894 the first legal instrument (Ordinance 2) was enacted leading to the creation of the Gwai and Shangani Reserves (Jordan 1983). A lot of Municipal Ordinances were subsequently enacted in 1924 which entrenched the white expropriation of African lands. The year 1973 saw the introduction of the Urban Councils Act (ibid). The Act led to the creation of a number of local Town Management Boards in big cities like Salisbury and Bulawayo. The legislation consolidated control of African Townships by the minority whites, coloureds and Asians.

The heavily controlled African Councils were later on expanded in the late 1970s?? The legislation facilitated the imposition of child-like and centrally defined programmes such that any pretence to promote African self government was thwarted by White supremacist policies (Jordan, 1983). Generally the pre-independence legislation was crafted to ensure total control of the ruling white colonialists' central government over the majority black community 
through some dummy defacto local authorities. It goes without saying therefore that the colonialists made use of legal instruments to intervene in and consolidate their stranglehold over the black populace. The legislation thus became "Achilles heel" of local authorities in the colonial era as it provided a boulevard for central control and any breach would be legally punished.

\subsection{The National Constitution}

The Zimbabwe Constitution, in its preamble, states that the "constitution is the supreme law of Zimbabwe and if any other law is inconsistent with this constitution that other law shall, to the extent of the inconsistency, be void". It therefore goes without saying that the national constitution as superior even to the Legislature. The Zimbabwe Institute (2005:15) argues that in that regard, the administrative and political culture in Zimbabwe highly regards those matters enshrined in the Constitution, which cannot be changed before careful review, consultation and defensible justification.

The Constitution of Zimbabwe is silent on the establishment of local government. It simply states in its preamble that the "constitution is the supreme law of Zimbabwe and if any other law is inconsistent with this constitution that other law shall, to the extent of the inconsistency, be void". The implication of this situation is that local authorities are not constitutionally protected. Since the constitution does not provide for a local government system, local authorities derive their authority from and are subject to the dictates of the Ministry of Local Government (MLG) where they are provided for though the Urban Councils Act and Rural District Councils Act.

The strength of the current legislative framework is that it can be easily changed and amended to suite the prevailing circumstances. Therein also lies its weaknesses which pose as the "mortal heel of Achilles". The Acts can be amended at any time by a simple two thirds majority in parliament to suit any political climate which might not necessarily be relevant to the local authorities and residents but the feuding political parties. Thus apart from being at the behest of partisan politics, the unconstitutionally protected local government of Zimbabwe has been is also at the mercy of the MLG. Local authority initiatives, annual budgets, revenue-raising initiative, by-laws and council resolutions as well as the hiring and firing of senior staff require approval by the MLG. Council resolutions can be reversed, rescinded and amended by the Ministry to the detriment of local interests.

According to Blunt (2011:03), MLG can investigate councils and act against them on virtually any matter, implying that even though councils are popularly elected, they are more of de-concentrated entities of the MLG rather than autonomous local governments. Locally elected officials essentially report to the MLG, and so they must be attuned to central ministry decision makers in Harare at least as much as to the local constituencies they were elected to represent (ibid). A common complaint amongst councillors is the excessive control that the MLG exercises over them, including the appointment of special interest and caretaker councillors. 
The Herald of 09 March 2012 carried a report where a misunderstanding was now growing in Harare as to who exactly calls the shots at the Harare City Council between The minister of Local Government, the Mayor and the residents. These scenarios underline that lack of constitutional protection poses the risk of local authorities being swallowed by the central Ministry. Blunt (2011: 03) likened the MLG relationship with the MDC-led councils to a "rider and a horse, respectively", local authorities being the latter.

It is however instructive to note that although the constitution is silent on the establishment of local government, it does provide for the appointment of chiefs and provincial governors. Sections 111 (1) of the Constitution provides for the appointment of Chiefs presiding over the tribes' people of Zimbabwe... and who shall be appointed by the President. Section 111 (2) provides for the establishment of a Council consisting of a number of Chiefs elected by the Chiefs from each of the various areas of communal land. Section 111 A provides for the appointment of Provincial, District and Regional governors. It reads, "For the better administration of Zimbabwe, an Act of Parliament may provide for the appointment by the President of governors for any area within Zimbabwe".

While the constitutionally provided offices are key to local government administration in Zimbabwe, the downside of these provisions is that they are deep-seated in central government control as the executive retains a major stranglehold on the offices through presidential appointments which may be high on political loyalty and low on technical and administrative expertise. In addition the specific powers and functions are referred to a "specific Act of Parliament which still can be amended in much the same manner as the Urban Councils Act and Rural District Councils Act.

\subsection{Urban Councils Act Chapter 29:15}

In Zimbabwe, the Urban Councils Act (UCA) [Chapter 29:15] provides for the establishment of urban local authorities as well as the manner of their operation. The legislation provides for the supervisory and monitoring roles of national government in the running of local authorities. Mushamba (2010: ) questions whether there is an appropriate balance between the need for oversight and the need for local discretion, whether checks and balances exist to guard against undue interference by central government in the affairs of local authorities and whether these checks and balances working. The Act has been criticised for being related to “Draco's harsh code of laws which gives the Minister unlimited powers over local authorities.

PART VIII of the Urban Councils Act provides for the establishment of the Local Government Board, composition and functions. Section I23 of the Act outlines the functions of the Board which among others entails provision of guidance and control to the functioning of council employees, conducting enquiries into council affairs and procedures and approval of the appointment and dismissal of senior council staff. The role played by the Board is highly significant but what is of concern however is the fact that, members to the Board are appointed by the Minister further reinforcing and entrenching central government intervention in council affairs. 
Section 4 of the Act provides for the establishment and upgrading urban councils by the President. It highlights that, "whenever the President considers it desirable .... he may (a) establish a municipal council or town council (b) divide the council area into any number of wards. It can be gleaned from the above statement that the central government is all over the place defining and directing all important functions in local authorities. It also appears that urban councils are reduced to spectators in their own field whilst central government champions local administration.

Section 314 of the Act empowers the Minister to direct a council to reverse, suspend or rescind any of its resolutions or decisions if he considers that the resolutions or decisions are not in the interest of the inhabitants of the area, or in the national or public interest. In addition, Section 53 of the Act provides that the Minister may also direct that certain resolutions shall require the Minister's approval failing which any such resolutions are invalid. Mushamba (2010:9) questions the denomination of what would be in the public or national interest or the interest of the inhabitants of the area. He further asserts that the cumulative effect of the Minister's powers to act on behalf of councils or to adopt bylaws or rescind council resolutions and decisions may undermine the council's ability to provide local solutions to local problems. It therefore follows that the rationale for ministerial intervention in local authorities is legally subject to the Minister's definition, satisfaction and discretion.

\subsection{Rural District Councils Act Chapter 29:13}

This is an Act to provide for the declaration of districts and the establishment of rural district councils; to confer and impose functions upon rural district councils and provide for the administration of their areas; and to provide for matters connected with or incidental to the foregoing.

Similar to the Urban Councils Act, Section 52(3) of the Rural District Councils Act (RDCA) empowers the Minister to direct a council to reverse, suspend or rescind any of its resolutions or decisions if the Minister considers that the resolutions or decisions are not in the interest of the inhabitants of the area, or in the national or public interest. Section 53 (1) and (2) of the RDCA also provides for the Minister to direct that certain resolutions shall require his approval failing which any such resolutions are invalid. Section 157 of the RDCA provides for the suspension of all or any of the councillors from exercising all or any of their functions by the President if he considers it necessary or desirable to do so in the public interest or in the interests of the inhabitants of the area. The President may also amend or revoke the suspension but where the President has not done so within 30 days the seat becomes vacant.

In addition a councillor whose suspension is not lifted is barred from being nominated for election as a councillor until the President has lifted the disqualification. According to Mushamba (2010:12) this provision raises interesting legal questions which include, for instance, when is it in the public interest to suspend a councillor? When is it in the interests of the inhabitants of the area for the President to suspend a councillor? Is the President obliged to consult the inhabitants of the area before suspending the councillor? 
The Act therefore appears to be singing the same song as the Urban Councils Act in terms of tightening and deep sitting central government's unquestionable legal grip on local authorities. The grounds for control and supervision are vague and loosely structured to such an extent that they are ultimately subject to central government discretion, a move which automatically strips the local authorities of their autonomy over local issues.

\subsection{Provincial Councils and Administration Act (Chapter 29:11)}

This is an Act to provide for the declaration of provinces within Zimbabwe and the appointment of provincial governors for such provinces; to provide for the establishment and functions of provincial councils. It also provides for the duties and functions of Governors and Resident Ministers and Provincial Administrators for the country's ten provinces. The governors are political heads of provinces appointed by the president. They are empowered to chair provincial councils which are the highest decision making authorities of provinces.

Section 10(b) of the Provincial Councils and Administration Act outlines that, Governors are supposed "to foster and promote the activities of the various ministries and organs of central Government in implementing development plans prepared by Provincial Councils". It is therefore apparent that the Governors are empowered to foster centrally driven objectives in local authorities. According to the Zimbabwe Institute (2005:9) the move to introduce the post of metropolitan Governor could be viewed as designed to neutralise the unwanted presence of the opposition MDC party that controlled the two cities of Harare and Bulawayo against the backdrop of the opposition having overwhelmingly won local council elections.

\subsection{Traditional Leaders Act (Chapter 29.17)}

The Traditional Leaders Act Chapter 29.17 provides for the appointment of village heads, headmen and chiefs; the establishment of a Council of Chiefs and village, ward and provincial assemblies and define their functions; provides for the issue of village registration certificates and settlement permits; repeals the Chiefs and Headmen Act [Chapter 29:01]; amends the Criminal Procedure and Evidence Act [Chapter 9:07], the Communal Land Act [Chapter 20:04] and the Rural District Councils Act [Chapter 29:13].

The Act provides acres of space for central government control over local authorities as the leaders are appointed by the president. The appointed leaders are empowered to preside over the grassroots village and ward assemblies which village and ward development committees are accountable to. The Minister is also awarded wide discretion as the evidenced by statements like, "Provided that the Minister may, where he considers it appropriate in the interests of good administration........" [Section 18(1)]. Thus the Minister can actually legally justify any intervention to do with the demarcation and constitution of communal areas. In addition the powers and functions conferred upon the traditional leaders may actually be a boulevard for duplication of duties, conflict of interest and power struggle between the parallel structures of tradition and council. This is an unhealthy relationship as the two structures should actually be integrative rather than conflicting. 


\subsection{Local Government Laws Amendment Act 2007}

The Local Government Laws Amendment Act was enacted in 2007 ushering in some changes in the Rural District Councils Act (Chapter 29:13), the Urban Councils Act (Chapter 29:15) and the Electoral Act (Chapter 2:13). The justification was for the purpose of making a provision for various matters arising from the Constitution of Zimbabwe Amendment (No. 18) and the Electoral Laws Amendment Act, 2007. Clauses 2 to 4 amend the Rural District Councils Act (Chapter 29:13). The amendments relate to the constitutional reassignment of the responsibility for dividing council areas into wards from the President to the Commission.

Clauses 5 to 30 amend the Urban Councils Act (Chapter 29:15). Some of the amendments relate to the constitutional reassignment (from the President to the Commission) of the responsibility for dividing council areas into wards and the abolition of non-synchronous local and national elections by the Constitution. More importantly, clauses 12 and 14 abolish the office of executive mayor, which was created in 1995. Incidentally to the abolition of the office of executive mayor, the executive committee of municipal councils is also abolished and its powers are re-vested in the council. This committee was an adjunct to the office of executive mayor. Together, the executive mayor-ship and executive committee were powerful decision making offices to the extent that they were regarded to have relegated the elected council to the status of a mere consultative body. Although certain powers were shifted to the council the downside of the amendment was to weaken local authorities as they lost executive powers.

The amendment also makes provision for the appointment by the Minister of non-voting councillors representing special interests not exceeding one quarter of the elected membership of a council. The appointed councillors will hold office "during the pleasure of the Minister". Such vague enunciations serve to provide too much discretion on the Minister to guarantee the lifespan of the councillors regardless of the opinions of the residents and elected councillors. The appointment itself although it might serve to blend the council and enhance health debate and discussion in council equally serves to strip the residents of their democratic right to elect representatives. Kamete (2006) referred the development as a "return of the Jettisoned" whereupon deposed and rejected candidates are brought back through the back door.

Kamete's sentiments were supported by unfolding events where the Newsday of 13 April 2012 carried a report entitled, "Villagers drag Chombo to Court". In the report the Minister had appointed five special interest councillors to the Matobo Rural District Council. The move did not go down well with the villagers who filed an urgent court application to reverse the appointments arguing that the five did not add value to the council as they were made up of the Minister's party allies and rejected candidates who had lost previous council and parliamentary elections.

Clause 16 repeals Section 80 of the Urban Councils Act, empowering the Minister responsible for local government to appoint a commissioner for an urban council area. Chakaipa (2010:11) argues that this provision gave the Minister discretionary power to perpetuate the continued existence of a commission. Instead of commissioners the Minister may appoint not more than three caretakers for a council that for any reason is deprived of all of its councillors, or cannot 
function because it is insolvent or does not have a quorum. The caretakers can only hold office for 90 days or until the next election of councillors, whichever occurs sooner. Although crisis situations always call for crisis management the fact that the caretakers are appointed instead of elected militates against principles of democracy and provides room for the Minister to arbitrarily and politically make appointments which do not necessarily solve the community's problems but suit the prevailing socio-politico climate.

\section{Institutional Framework}

\subsection{The Ministry of Local Government Rural and Urban Development}

The Ministry forms the apex of the Local Government system which is responsible for the broader formulation and implementation of Local Government policy. It provides the legislative and policy framework within which local government units operate. The ministry also administers the various statutes which establish and operationalise local government in Zimbabwe. It is finally accountable to the Nation, Parliament and the Executive for the efficient operation of local government.

The enabling legislation in Zimbabwe provides the Ministry with unlimited powers over local authorities. The ministry is enabled to monitor direct and supervise local authorities to ensure efficient service delivery. The governing legislation treats the Minister as the ultimate discretionary decision maker on local authorities matters as witnessed by statements like, "The Minister shall.....", "If it is in the Minister's best interest........" and "....shall hold office during the pleasure of the Minister". Such provisions provide the Minister with unlimited discretion over how best he/she wants to manage local authorities.

Functionally, the Ministry is supposed to provide an enabling or facilitative framework within which local government operates. The Zimbabwe Institute (2005:4) argues that in practice, however, the ministry of Local Government has increasingly played a controlling and directive role especially since the emergence of a formidable opposition (MDC) with a significant control over Local Government authorities in the urban areas. The Ministry can therefore operate as the central government's tool for harnessing local authorities and stamp out any democratic manoeuvres by threatening opposition parties.

The local government legislation in Zimbabwe invests the President and the Minister of Local Government with the power to suspend or act in place of a local authority and the power to nullify some decisions of local authorities, reverse rescind and suspend council resolutions. The Zimbabwe Institute (2005: 5) outlines that this is evidenced by the RDC Act where there are more than 250 instances where the Minister can intervene in the day to day running of Rural District Councils. The Minister can also suspend and dismiss democratically elected mayors and councillors and replace them with appointed commissions and councillors. Such provisions militate against the democratic principles of decentralisation and self governance. It therefore appears as if the process of decentralisation in Zimbabwe is only a dummy or shadow of the intended ideals. The level of central control is so gross that the Financial Gazette of 03 February 2012 described the local governance dynamics as "Blood 
bath in councils".

\subsection{Local Government Board}

The Local Government Board is provided for under section 116 of the Urban Councils Act. According to the Act it shall consist of seven members appointed by the Minister, of whom:

(a) One shall be chosen from a list of not less than three names submitted by the Urban Councils Association;

(b) One shall be chosen from a list of not less than three names submitted by the town clerks;

(c) One shall be chosen from a list of not less than three names submitted by the Municipal Workers Union;

(d) One shall be a member of the Public Service Commission chosen from a list of not less than three names submitted by the Minister responsible for the Public Service;

(e) Two shall be appointed for their ability and experience in public administration and who are or have been employed by a local authority or the Public Service for a period of not less than five years in a senior post.

The composition of the Board appears broad based and ideal for effective local governance. The only challenge is however on the implementation and usual discretion afforded to the Minister. For instance subsection (3) of Section 116 provides that if any person or organization referred to in subsection (2) fails or refuses to nominate a person to the Local Government Board when required to do so by the Minister, the Minister may appoint any person to represent that organization, and the person so appointed shall hold office as a member in all respects as if he had been duly nominated and appointed in terms of subsection (1). The challenge to local governance now is the opportunity for the Minister to subjectively appoint individuals who are loyal to him or sympathetic to the party's ideology at the expense of local interests.

The main function of the Board is to provide guidance for the general organisation and control of employees in the service of councils. This function has been highly contentious in the modern local government system as the Board has been on a spree of investigations, suspensions and dismissals of elected councillors and mayors particularly those from the opposition parties. On top of the composition another critical area has been on the powers conferred upon the board which some respondents view as reducing councillors to "ball boys". For instance Section 123 (2) provides that, In the exercise of its functions in terms of this Act, the Local Government Board may or, where so directed by the Minister, shall:

(a) Require any council or any councillor, employee or agent of a council to produce any document, book or other record;

(b) Summon and examine any witness who the Board considers may be able to assist it in the 
conduct of any inquiry; and

(c) Obtain information and advice from any council or any employee or agent of any council.

The powers conferred thereto are necessary for an authority exercising disciplinary action but provided that the authority is impartial. The question therefore goes back to the composition of the Board and the prevailing political climate.

\subsection{Provincial Governor's Office}

Provincial Governors are political office bearers and Resident Ministers of provinces appointed by the President on the basis of eligibility for election as a member of parliament. Each province in Zimbabwe therefore has a provincial governor who chairs the provincial council. The council is in turn responsible for:

(a) Promoting the development of the province;

(b) Formulating policies, both long-term and short-term, for the province;

(c) Preparing annual development and other plans for the province;

(d) Reviewing and evaluating the implementation of development plans and policies within the province;

It is apparent that Provincial Governors hold powerful positions in society necessary for spearheading local development. The downside of this institution however is that the Governors are appointed rather than elected hence the legislation can actually pave way for a "return of the jettisoned" as the President can legally appoint individuals who have been rejected by the electorate in parliamentary elections.

\subsection{Traditional Leadership}

The local government system in Zimbabwe like most African countries is characterised by the existence of hereditary (traditional) leadership paralleled with elected (Council) leadership. The end result has been that of conflicting claims of legitimacy and uneasy co-existence between elected and traditional leaders particularly in the rural areas. The arrangement provides a platform for traditional leaders and local government officials to trade accusations of abuse of power, non-compliance with law, customs and traditions.

To make matters worse although traditional leaders are meant to be ceremonial leaders they derive power from the national constitution a privilege which councils actually do not have. For instance the Council of Chiefs is provided for in the Constitution of Zimbabwe and under the Traditional Leaders Act. Members of the Council of Chiefs are chosen by a Provincial Assembly of Chiefs and the Council in turn elects ten of its members to sit in the Zimbabwe Parliament as non-constituency MPs. In addition Chiefs are also entitled to be paid by the State an allowance or salary that is decided by the government through an Act of Parliament. 
Such provisions have an impact of highly skewing traditional leaders' allegiance to central government interests as opposed to the local community's interests.

Makumbe (2010:7) argued that although traditional leaders have been stripped of a number of local government responsibilities which were subsequently extended to local authorities, the central government through the ruling ZANU PF party has gone back to the drawing back using colonial tactics of manipulating the rural populace through the traditional leaders. Makumbe further argues that faced with the same fate of having to deal with a restive population, the ruling party has decided to turn back the clock by revisiting a classic case of how those who were expected to stand with the people decided to sell out. Sensing imminent defeat in the last parliamentary election, the party suddenly remembered the chiefs by awarding them allowances, subsequently installing electricity in their homes and periodically increasing their allowances without them having lifted a finger. As argued by Makumbe this is a classic case of history repeating itself as grateful of this generosity, chiefs are alleged to have since helped in making rural areas a no go area for the opposition and flashpoints for those considered not loyal to the 'revolution'.

\subsection{Ward and Village Development Committees}

These are grass root structures created through the Prime minister's directive of 1984 for the identification and articulation of village needs, organizing people to undertake communal projects as well as cooperating with government extension workers in development planning. The major weakness of these structures is the lack of legal autonomy and sufficient resources to effectively discharge services. ACPD (2010) described decentralization to the VIDCOs and WADCOs as "phony decentralization" which has produced structures lacking power and resources to have meaningful effectiveness.

\section{Conclusion}

In pre-independence Zimbabwe the colonial masters manipulated the legal and institutional framework of local governance to consolidate central government stranglehold on local authorities. The main aim was to further racial control and minority central interests of the ruling white regime. Upon independence in 1980 Zimbabwe strived towards significant political and administrative decentralization through the creation of decentralized structures up to the village level. The structures were established through various legal instruments which include the Urban Councils Act, Rural District Councils Act, Provincial Councils and Administration Act and the Traditional Leaders Act. The legislation has been the "Achilles heel" of local authorities as it is the most vulnerable part in the local government system which confers unlimited discretion to the central government over local authorities and a boulevard for unquestioned ministerial intervention.

\section{References}

ACPD (2010) Local governance finance in Zimbabwe African Community Publishing and Development Trust. Harare 


\section{Macrothink}

Journal of Public Administration and Governance ISSN 2161-7104 2012, Vol. 2, No. 3

Blunt G. (2011) “Overcoming a decade of crisis: Zimbabwe's Local Authorities in transition” Journal of Public Administration and Development 31, 340-350 (2011)

Chakaipa S. (2010) "Local government institutions and elections" Local Government Working Paper Series No. 4 Community Law Centre, University of Western Cape

Jordan J. D. (1984) Local Government in Zimbabwe: An Overview The Mambo Press Gweru

Helmsing H.H, (1990) "Transforming Rural Local Government, Zimbabwe Post Independence Experience," 1990, No.01.04.02

Kamete A. (2006) "The Return of the Jettisoned: ZANU-PF's Crack at 'Re-Urbanising' in Harare" Journal of Southern African Studies, Volume 32, Number 2, June 2006 , pp. $255-271(\overline{17})$

Machingauta N. (2010) "Supervision of local Government in Zimbabwe" Local Government Working Paper Series No. 6 Community Law Centre, University of Western Cape

Makumbe J. (2010) "Local Authorities and Traditional leadership" Local Government Working Paper Series No. 2 Community Law Centre University of Western Cape

Mushamba S. (2010) "The powers and functions of local government authorities" Local Government Working Paper Series No. 5 Community Law Centre University of Western Cape

Olowu D. (2001) "Decentralization Policies and Practices under Structural Adjustment and Democratization in Africa" Democracy, Governance and Human Rights Paper Number 4 July 2001 United Nations Research Institute for Social Development

Zimbabwe Institute (2005) Local Government: Policy Review Zimbabwe Institute Cape Town.

\section{Legislation}

Local Government Laws Amendment No. 12008.

Provincial Councils and Administration Act [Chapter 29:1].

Rural District Councils Act [Chapter 29:13].

Traditional Leaders Act [Chapter 29:17].

Urban Councils Act [Chapter 29:15].

\section{Newspapers}

Newsday "Villagers drag Chombo to court" 13 April 2012 


\section{Macrothink}

The Herald "Why wait for Intervention" 09 March 2012

\section{Copyright Disclaimer}

Copyright reserved by the author(s).

This article is an open-access article distributed under the terms and conditions of the Creative Commons Attribution license (http://creativecommons.org/licenses/by/3.0/). 